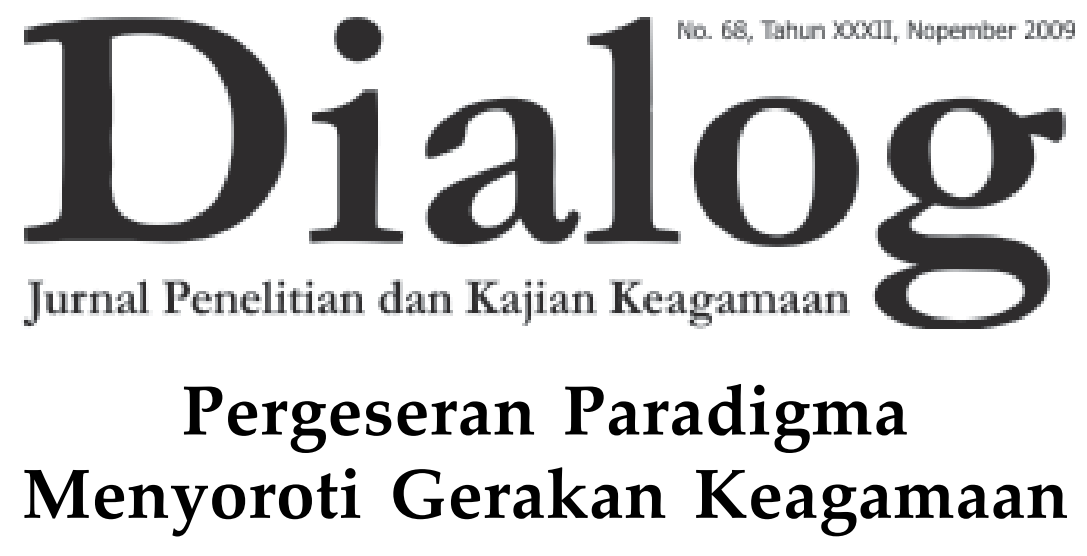




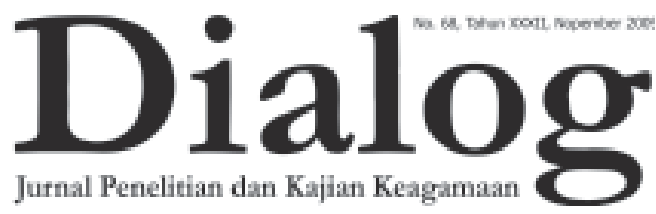

Pemi mpin Umum:

Prof. Dr. H. M. Atho Mudzhar, MA

Redaktur Ahli:

Prof. Dr. H. Nasaruddin Umar, MA

Prof. Dr. H. Komarudin Hidayat, MA

Pemimpin Redaksi / Penanggung J awab

Drs. H. Syamsuddin

Wakil Pemi mpin Redaksi

H. Fanani Suprianto, SH., MM

Sekretaris Redaksi

M. Rosyid Fauzi, S.Si.

Dewan Redaksı

Prof. Dr. H. Abdurrahman Mas'ud Drs. Amin Haedari

Prof. Dr. H. Maidir Harun

Drs. H. Mohammad Shohib, MA

Drs. H. Asmu'i, SH, MM

Chamdi Pamudji, SH., MM

Redaktur Eksekutif

M. Nasir, S.Th.I.

Redaktur Pelaksana

Moh. Rosyid Fauzi, S.Si

M. Nasir, S.Th.I

M. Adlin Sila, M.A

Abbas Jauhari, M.Ag

Administrasi

Drs. Dedy Curipno

Sutidjah

Desriyanti Nasution, S.IPI

Drs. H. Sahlani

Alamat Redaksi

Gedung Bayt Alquran Museum Istiqlal Komplek Taman Mini Indonesia Indah

Telp. (021) 87791444-87794982

Website:

www. balitbangdiklat.depag.go.id

Email:

info@depag.web.id

\section{Pergeseran Paradigma Menyoroti Gerakan Keagamaan}

Fenomena munculnya berbagai aliran keagamaan di Indonesia beberapa tahun terakhir menunjukan kecenderungan positif dalam kebebasan beragama. Namun sayangnya kebebasan menampilkan ekspresi keberagamaan tersebut kerapkali melampaui dari apa yang semestinya. Hal tersebut dapat kita lihat dengan munculnya gerakan keagamaan yang mengusung berbagai macam ajaran, ritual keagamaan yang aneh bahkan cenderung mengancam serta menodai kesucian aqidah, ibadah, ritual, dan pendirian mayoritas ummat yang sudah mapan. Sejak tahun 1989, setidaknya telah ada beberapa aliran keagamaan diberikan label haram oleh MUI (Majelis Ulama Indonesia), diantara aliran yang dianggap menyesatkan itu antara lain: Islam Jama'ah, Ahmadiyah, Ingkar Sunnah, Qur'an Suci, Sholat Dua Bahasa, Lia Eden dan al-Qiyadah al-Islamiyah.

Fenomena ini ditenggarai oleh sebagian pihak sebagai akibat dari kegagalan dakwah. Para da'i dianggap tidak mampu mentransformasikan nilainilai ajaran Islam secara kaffah 
(komprehensif) kepada ummat, dakwah selama ini sering bersifat eksklusif, menghakimi dan memprovokasi. Aktifitas dakwah hanya menampilkan Islam dari aspek langit atau 'ubudiyah (habluminallah) bukan aspek bumi dimana kehidupan sosial (habluminannas) bergulir, sehingga wajar berbagai permasalahan sosial yang dialami ummat tidak tersentuh. Fakta ini menyebabkan ummat mencari solusi lain atas permasalahan sosial yang mereka alami dengan cara "selingkuh" yaitu menganut sekte atau aliran baru dalam sebuah agama yang menawarkan solusi instan, namun cenderung "menyesatkan".

Para da'i, tokoh masyarakat, maupun para pemegang kebijakan ke depan harus mampu merubah paradigma yang selama ini salah dan telah mengkristal di kalangan ummat. Mereka diharapkan tidak berperan sebagai juru dakwah, juru vonis, juru putus, yang hanya menyampaikan pesan bil lisan di atas mimbar saja, tapi lebih dari itu, merek dituntut menjadi -meminjam istilah Clifford Geertz- cultural broker (makelar budaya), bahkan menjadi intermediary forces (kekuatan perantara) bagi permasalahan sosial ummat dalam istilah Hiroko Horikoshi.

Dalam kajian Jurnal Dialog Edisi ini mencoba mengulas tentang Pergeseran Paradigma Menyoroti Gerakan Keagamaan yang kerapkali menghadirkan tematema aktual di tengah-tengah masyarakat. Kajian Jurnal Dialog edisi ini diawali dengan tulisan Prof. Dr. H.M.
Atho Mudzhar tentang Instrumen Internasional dan Peraturan Perundangan Indonesia tentang Kebebasan dan Perlindungan Beragama. Dilanjutkan dengan tulisan Prof. Dr. Abdurrahman Mas'ud yang mengupas tentang Menyikapi Keberadaan Aliran Sempalan.

Sukris Sarmadi, Dosen STAIN Banjarmasin menghadirkan tulisan tentang Transformasi NU dalam Masyarakat Banjar Kini PerspektifPergeseran Gerakan Keagamaan di Kalimantan Selatan. Sedangkan M. Ulinnuha Khusnan, MA melalui tulisannya mencoba memotret Paradigma Keberagamaan Kaum Santri. Nurhasanah dosen UIN Jakarta menghadirkan tulisan tentang Politik Kebijakan Islamisasi Mahathir. Kajian jurnal dialog edisi ini kian lengkap dengan hadirnya tulisan Anwar Mujahidin, MA, tentang Science And Religion (Paradigma Al-Qur'an untuk IlmuIlmu Sosial Menurut Pemikiran Kuntowijoyo).

Di samping memuat artikel ilmiah, Jurnal Dialog edisi ini juga memuat laporan hasil penelitian oleh Ridwan Bustaman, tentang Analisis Wacana Kritis : Tayangan Kekerasan dalam Sinetron Bernuansa Keagamaan. Dan juga hasil penelitian saudara Basuki tentang Pesantren, Tasawufdan Hedonisme Kultural (Studi Kasus Aktualisasi Nilai-nilai Tasawuf dalam Hidup dan Kehidupan di Pondok Pesantren Modern Gontor). Serta hasil penelitian saudari Maryam tentang Interaksi Sosial Pelaku Konversi Agama Etnik Cina.

Kajian ini diakhiri dengan telaah 
buku yang mengulas buku karya Prof. Abdurrahman, 2009 yang berjudul Menebar Rahmat bagi Sekalian Alam. Semoga kajian yang dihadirkan Jurnal Dialog edisi ini memberikan manfaat yang berarti bagi para pembaca, khususnya dalam kajian Pergeseran Paradigma Menyoroti Gerakan Keagamaan. Selamat Membaca!

Redaksi

4 Dialog No. 68, Tahun XXXII, Nopember 2009 
TOPIK

M. Atho Mudzhar

Instrumen Internasional dan Peraturan Perundangan Indonesia tentang Kebebasan dan Perlindungan Beragama - -6

Abdurrahman Mas'ud

Menyikapi Keberadaan Aliran Sempalan --16

SUKRIS SARMADI

Transformasi NU dalam Masyarakat Banjar Kini Perspektif Pergeseran Gerakan Keagamaan di Kalimantan Selatan - 25

\section{Ulinnuha KhuSNAN}

Memotret Paradigma Keberagamaan Kaum Santri —41

\section{NuRHASANAH}

Politik Kebijakan Islamisasi Mahathir —65

\section{Anwar Mujahidin}

Science And Religion (Paradigma Al-Qur'An untuk Ilmu-Ilmu Sosial Menurut Pemikiran Kuntowijoyo) -78

\section{PENELITIAN}

\section{RidWAN Bustamam}

Analisis Wacana Kritis : Tayangan Kekerasan dalam Sinetron Bernuansa Keagamaan $\longrightarrow 97$

\section{BASUKI}

Pesantren, Tasawuf dan Hedonisme Kultural (Studi Kasus Aktualisasi Nilainilai Tasawuf dalam Hidup dan Kehidupan di Pondok Pesantren Modern Gontor) -112

MARYAM

Interaksi Sosial Pelaku Konversi Agama Etnik Cina --135

\section{BOOK REVIEW}

\section{Dewi $\mathbf{N}$}

Menebar Rahmat bagi Sekalian Alam —149 


\title{
Science And Religion (Paradigma Al-Qur'an Untuk Ilmu-ilmu Sosial Menurut Pemikiran Kuntowijoyo)
}

\author{
OLEH : ANWAR MUDJAHIDIN *)
}

\begin{abstract}
Abstrack
This paper aims at analyzing the epistemology of prophetic social science which had proposed by Kuntowijoyo. Sociology as a science cannot decide the direction in which society ought to go, and it makes no recomendations on matter of social policy. Sociology cannot itself deal with problems of good and evil, right and wrong, better and worse, or any others that concern human values. On the other hand religions without any knowledge of social phenomena will not be able to make any changes in the society. Prophetic social science will be able to respond to those dillemas by making the revelation (wahyu) as a source of knowledge. Social sciences do not only produce of statement about what is, but what of value. It can direct where the society ought to changes. According to prophetic social science changes must be directed to humanisation, liberation and trancendency.
\end{abstract}

KATA KunCI :

Ilmu Sosial, al-Qur'an, Epistemologi

\section{A. Latar Belakang}

Hubungan antara agama dan ilmu sosial yang tidak rukun sudah saatnya diakhiri karena terbukti perceraian dan bahkan konflik antara keduanya samasama tidak membawa keberuntungan bagi masyarakat yang menjadi orientasi baik dari agama maupun ilmu sosial. Secara universal agama merupakan ajaran yang dapat mempengaruhi sifatsifat manusia seperti ketika seseorang menikmati matahari terbenam atau terpesona melihat keindahan langit yang dipenuhi bintang-bintang di

*) Dosen IAIN Sunan Ampel Surabaya malam hari. Dalam kondisi kekaguman yang demikian seringkali muncul suatu kesadaran yakni kesadaran diri mengenai hal-hal ghaib. Agama muncul dalam kehidupan pribadi ketika menghadapi kelahiran dan kematian, penyakit dan tragedi, rasa bersalah dan keputus asaan, atau dalam keadaan tidak sadarkan diri atau melakukan meditasi. ${ }^{1}$ Namun agama tidak hanya memiliki dimensi universal, ia juga memiliki dimensi sosial dan institusional.

\footnotetext{
${ }^{1}$ Holmes Rolston, Science and Religion a Critical Survey (New York: Random House, 1987) h. 221222
} 
Menurut Durkheim, tidak ada agama tanpa gereja. Agama (yang universal) direproduksi dari kultus dan ritual, sakramen, festival, layanan, upacara, dan tarian. Sepuluh perintah dilaksanakan atas nama Yahweh, dimulai dari Sinai, dan membuat aturan-aturan sosial untuk orang-orang Israel, melindungi keluarga, kehidupan, anak-anak, harta, kebenaran, dan pengaturan hari Sabat sebagai suatu kontrak yang sifatnya mengikat. Agama memberikan landasan sosial untuk membentuk masyarakat secara bersamasama, maka tidak ada agama yang dapat bertahan hidup tanpa mengetahui fungsi analisis ilmu sosial. ${ }^{2}$

Pandangan yang menyatakan bahwa ilmu-ilmu sosial adalah bebas nilai terbukti juga hanya mitos belaka. Konsep tentang bebas nilai sangatlah tidak jelas, sehingga perlu dicermati secara lebih dalam. Ketidakjelasan tersebut semakin nyata, ketika para ilmuan sosial memberikan kontribusi keilmuan yang bersifat ramalan bahwa agama akan punah, padahal ilmu-ilmu sosial sendiri tidak dapat menyediakan nilai-nilai yang dibutuhkan masyarakat sebagai pengganti agama. Karena itu tidak mungkin ilmu sosial itu bebas nilai dan mengharapkan ilmu sosial yang bebas nilai berarti mengimani obyektivitas ilmu sosial, di mana semua itu hanyalah mitos dan khayalan belaka. $^{3}$

Mencermati dua kenyataan ilmu sosial dan agama di atas, Rolston menyatakan bahwa tanpa menyangkal teori-teori sosial yang telah berhasil menjelaskan fenomena sosial baik yang mekanis, organis, fungsional, maupun sibernetik, harus diakui bahwa masyarakat itu pada pokoknya penuh dengan makna (meaningfullness). Corak sistem sosial manusia yang dibuat dalam kapasitas psikologis adalah masyarakat itu membawa makna (society carries meaning) untuk itu perlu perpindahan fokus kajian sosiologis dari teknik ke harga, dari fakta ke pertimbangan nilai, dan dari sains ke kebijaksanaan. Para ahli teori sosial terkemuka, sudah lama menyatakan bahwa pemahaman terhadap masyarakat tidak hanya memerlukan suatu analisa objektif terhadap kekuatan sosial, konflik, equilibria, fungsi, dan semacamnya, tetapi suatu penafsiran empatik terhadap weltanschaung (pandangan hidup) para aktornya. ${ }^{4}$

Kuntowijoyo mengistilahkan teoriteori sosial yang dianggap Rolston tidak dapat berempati dengan nilai-nilai agama seperti organisme, sistem keseimbangan, struktural fungsional, sibernetik, dan konflik sebagai ilmu sosial akademik. Sosiologi akademis tersebut ternyata tidak value free sebagaimana diklaim oleh kaum fungsionalis, tetapi tetap berpihak. Memilih teori, pengumpulan data, klasifikasi data, dan interpretasi atas fakta, semuanya ternyata merupakan ketidakbebasan. Laporan-laporan sosiologi di Amerika berpihak pada yang kuat, misalnya berpihak kepada mayoritas orang kulit putih, tidak kepada kulit hitam. Netralitas ilmu sosial empiris-analitis juga patut diragukan karena selalu menghasilkan ilmu-ilmu yang nomologis, menerangkan saja tanpa

Ibid., h. 220-221

Holmes Rolston, Science and Religion, h. 226-

${ }^{4}$ Ibid, h. 210 
mengandung nilai moral mengenai tujuan. ${ }^{5}$

Pandangan Rolston tentang ilmuilmu sosial dan agama yang juga disetujui oleh Kuntowijoyo dan banyak cendekiawan lainnya, membuka hubungan baru yang lebih objektif dan interaktif antara ilmu-ilmu sosial dan agama dalam melihat realitas sosialkultural suatu masyarakat. Ilmu-ilmu sosial menjadi lebih mampu membatasi diri untuk tidak menghakimi agama sebagai wilayah yang naïf dan primitive dan agama juga mampu mengembangkan wilayah-wilayah historisnya sehingga dapat mengikuti irama perubahan. Di Indonesia pemikiran yang lebih interaktif antara ilmu sosial dan agama juga menggema baik dikalangan pakar ilmu sosial maupun ilmu-ilmu agama. Semangat kajian tersebut selain dilatar belakangi perkembangan kajian keilmuan itu sendiri, juga dilatabelakangi oleh kondisi real masyarakat yang dianggap beragama namun terpuruk dalam kancah masyarakat modern. Para cendekiawan merasa gelisah mengapa masyarakat bependuduk mayoritas muslim ini tidak dapat maju dan menjadi modern. Namun disisi lain sebagaimana dinyatakan oleh Moeslim Abdurrahman dalam bukunya Islam Transformatif mereka juga sedang mengkhawatirkan hilangnya idealisme agama dalam masyarakat yang sedang berubah. ${ }^{6}$

Kegelisahan di atas telah melahirkan kelompok intelektual yang kritis baik terhadap modernisme dalam pengertian

${ }^{5}$ Kuntowijoyo, Islam Sebagai Ilmu, Epistemologi, Metodologi, dan Etika (Bandung: Teraju Mizan, 2004) h. 99

${ }^{6}$ Moeslim Abdurrahman, Islam Transformatif, (Jakarta: Pustaka Firdaus, 1997) h. 194 ilmu pengetahuan dan kebudayaannya, maupun tradisi dalam pengertian bangunan ilmu-ilmu agama yang dipahami oleh masyarakat. Di antara cendekiawan yang terlibat intensif dalam perdebatan tersebut sejak awal masa orde baru adalah Nurcholis Madjid, Djohan Effendi, Mukti Ali, Dawan Rahardjo, Muslim Abdurrahman dan Kuntowijoyo. Menurut Dawam, Moeslim Abdurrahman dan Kuntowijoyo adalah wakil dari generasi baru dalam perkembangan pemikiran Islam pasca "pembaruan" Nurcholish Madjid yang oleh kalangan muda disebut sebagai Teologi Pembangunan yang cenderung berfungsi legitimatif terhadap kekuasaan dan gagasan modernisasi. $^{7}$

Kegelisahan Moeslim Abdurrahman dimulai ketika melihat sinyal adanya ambivalensi dalam masyarakat dimana intensitas ritual menjadi sangat romantik, akan tetapi tidak selalu membuahkan kesalehan diri, apalagi kesalehan sosial. Kehidupan beragama seolah-olah menjadi sangat rutin, tanpa keprihatinan yang melahirkan tanggungjawab sosial. Agama lebih dihayati sebagai penyelamatan individu dan bukan sebagai keberkahan sosial secara bersama. Seolah Tuhan tidak hadir dalam problematik sosial kita, kendati namanya semakin rajin disebut di mana-mana. ${ }^{8}$ Untuk itulah ia menawarkan teologi transformatif. Teologi ini ditawarkan sebagai alternatif terhadap teologi pembangunan.

Kuntowijoyo tidak setuju dengan konsep teologi transformatif yang

\footnotetext{
7 M. Dawam Rahardjo, Intelektual Intelegensi dan Perilaku Politik Bangsa (Bandung: Mizan, 1999) h.

${ }^{8}$ Moeslim Abdurrahman, Islam Transformatif, 194-195
} 333 
ditawarkan oleh Moeslim Abdurrahman bahkan termasuk semua gagasan pemabaharuan teologis. Menurut Kunto, konsep teologi itu tidak dikenal oleh umat Islam, andaikan ada yang berbicara tentang teologi maka yang dimaksud adalah ilmu kalam dan ilmu ushuluddin yang membicarakan soal tauhid atau konsep ketuhanan menurut Islam. Topik pembahasan tersebut menurut Kunto bukan persoalan yang dihadapi oleh umat Islam. Persoalan yang dihadapi oleh umat Islam adalah bagaimana memahami dan menanggapi realitas dengan tindakan-tindakan yang dapat mengubah keadaan sesuai dengan arah petunjuk Tuhan. Sebagai ganti teologi Kunto menawarkan Ilmu-Ilmu Sosial Profetik. ${ }^{9}$

Sebagai pakar sejarah sosial, namun juga agamawan dan budayawan, Kunto tidak ingin memulai kajiannya dari atas dengan mereformasi sistem normatif agama, tetapi berangkat dari bawah yaitu problem-problem riil di masyarakat. Dengan ilmu sosial bukan teologi, Kunto ingin menegaskan bahwa lingkup kajiannya bukan pada aspekaspek normatif yang bersifat permanen, tetapi pada aspek-aspek yang bersifat empiris, historis, dan temporal. Dengan tawaran istilah ilmu sosial, harapan kunto, kajiannya tidak diberi pretensi doktrinal, karena Kunto juga mengakui relativitas ilmu. ${ }^{10}$

Gagasan Kuntowijoyo di atas, jelas memberi harapan yang cerah terhadap masalah besar dalam kajian-kajian sosiologis tentang hubungan agama dan science, antara yang normatif dan obyektif, bagaimana menjelaskan hubungan antara masalah keyakinan

${ }^{9}$ Dawam Rahardjo, Intelektual Intelegensi, h. 332

10 Kuntowijoyo, Islam Sebagai Ilmu, h. 90 kepada kekuatan yang ghaib (supranatural) dengan manusia sebagai aktor dalam perubahan sosial. Kunto menolak ilmusosial yang kenyataannya tidak bebas nilai, padahal ia hanya mampu menjelaskan fenomena-fenomena sosial tanpa memberitahukan kearah mana masyarakat harus berubah. Selanjutnya Kunto menawarkan satu paradigma baru untuk ilmu-ilmu sosial sehingga terbangun ilmu sosial yang mampu dipakai untuk transformasi masyarakat dengan nilai-nilai agama. Kerangka paradigma yang disebut kunto sebagai rancang bangun (epistemologi, metodologi, dan etika) ilmu sosial transformatif sebagai struktur fundamental ilmu-ilmu sosial inilah yang menarik dan akan menjadi fokus kajian dalam makalah ini.

\section{B. Biografi Singkat Kuntowijoyo}

Kuntowijoyo lahir di Sorobayan, Bantul, Yogyakarta pada 18 September 1943. Gelar sarjananya diperoleh tahun 1969 di Fakultas sastra jurusan sejarah UGM. Program MA ia selesaikan di Universitas Connecticut USA dan Memperoleh gelar Philosophy Doctor (Ph.D) dalam bidang ilmu sejarah dari Colombia University pada tahun 1980. Disertasi Kunto berjudul Social Change in an Agrarian Society: Madura 1850-1940. Beliau adalah dosen di Universitas Gadjah Mada (UGM). Selain sebagai intelektual yang produktif dengan tulisan-tulisan ilmiah, beliau adalah seorang sastrawan.

Cerpen pertamanya yang memperoleh penghargaan dari majalah Sastra pada tahun 1968, berjudul: "Dilarang Mencintai Bunga-Bunga". Menulis naskah drama "Rimputrumput Danau Bento" memenangkan hadiah harapan dari BTPN tahun 1968. 
Naskah drama yang lain "Topeng Utan Kayu" memperoleh hadiah dari Dewan Kesenian Jakarta tahun 1973. Belau juga menulis novel, diantara, "Kereta Api Yang Berangkat Pagi Hari" (1966), "Pasar" (1972) mendapat hadiah panitia hari buku, "Khotbah di atas Bukit" (1976). Beliau juga menulis puisi, kumpulan pusinya "Suluk AwangUwung" (1975) dan "Isyarat" (1976).

Atas karya-karyanya dibidang sastra ia memperoleh penghargaan antara lain: Penghargaan Penulisan Sastra Pusat Pembinaan dan Pengembangan Bahasa (1994), Penghargaan Kebudayaan ICMI (1995) dan cerpen terbaik Kompas (1995, 1996, 1997), ASEAN Award on Culture (1997), Satya Lencana Kebudayaan RI (1997), Mizan Award (1998), Penghargaan Kalyanakretya Utama untuk Teknologi Sastra dari Menristek (1999) dan S.E.A. Award dari Kerajaan Thailand (1999).

Buku yang sudah diterbitkan adalah Dinamika Sejarah Umat Islam Indonesia (Yogyakarta: Shalahuddin Press, 1985), Budaya dan Masyarakat (Yogyakarta: PT Tiara Wacana, 1987), Paradigma Islam: Interpretasi Untuk Aksi (Bandung: Mizan, 1991), Identitas Politik Umat Islam (Bandung: Mizan, 1997), Muslim Tanpa Masjid (Bandung: Mizan, 2001) dan Islam Sebagai ilmu, Epistemologi, Metodologi, dan Etika (Bandung: Teraju Mizan, 2004). Selain itu masih seabrek tulisan baik yang dimuat diberbagai media cetak, Kompas, Republika, maupun yang tidak dimuat.

\section{Modernisme dan Saintisme}

August Comte (abad 19 M), bapak sosiologi modern menyatakan bahwa peradaban modern terjadi bila manusia telah berpikir positif (rasional) meninggalkan tahap berpikir teologis dan metafisik. Bila pada tahap berpikir teologis manusia percaya bahwa di balik gejala-gejala alam terdapat kekuasaan adikodrati yang mengatur segalanya kemudian pada zamam metafisika manusia masih dikuasai oleh kekuasaan adikodrati namun melalui konsepkonsep dan prinsip-prinsip yang abstrak seperti "kodrat" dan "penyebab" maka pada zaman yang disebut positif sudah tidak ada lagi penyebab yang ada dibelakang fakta-fakta. Atas dasar observasi dan dengan menggunakan rasionya manusia berusaha menetapkan relasi-relasi atau urutan-urutan yang terdapat di antara fakta-fakta. Dalam zaman inilah manusia baru dicatat sebagai penghasil ilmu pengetahuan yang sesunggunya. ${ }^{11}$

Pada tahap befikir rasional itulah ilmu pengetahuan masa modern membangun metodologi yang menjamin kebenaran temuantemuannya dan menganggap keyakinan dan kebenaran agama sebagai yang naif dan subyektif. Bahkan lebih dari itu, masyarakat yang berpola pikir nonrasional yang diidentikkan dengan bangsa timur, non barat dianggap sebagai masyarakat berbudaya primitive. Sebagaimana diceritakan Muhadjir, di perguruan tinggi Indonesia sampai tahun 1950-an di ajarkan pembedaan antara gemeinschaft atau masyarakat paguyuban, masyarakat timur yang masih primitive dengan gessellschaft atau masyarakat patembayan yaitu masyarakat barat yang sudah maju. ${ }^{12}$

Tesis August Comte di atas diragukan banyak ahli dikemudian hari,

11 Kaelan, Filsafat Bahasa, Masalah dan Perkembangannya, (Yogyakarta: Paradigma, 1998) h. $75-76$

12 Noeng Muhadjir, Filsafat Ilmu, Kualitatif dan Kuantitatif untuk Pengembangan Ilmu dan Penelitian, Edisi III (Yogyakarta: Rake Sarasin, 2006) h. 101 
karena pada kenyataanya modernisme tidak serta merta menyingkirkan agama dan agama juga tidak identik dengan primitivisme. Menurut Rolston, sosiologi model Comtean yang didasarkan pada determinisme sulit untuk dipraktekkan pada masa sekarang. Comte menyatakan bahwa tahap agama dan filosofis (metafisik) adalah salah, ia sangat bangga dengan era sains yang datang menggantikan tahap sebelumnya. Jika tahap yang terakhir terjadi secara otomatis, maka dengan cara apa untuk menghilangkan tahapan-tahapan sebelumnya?, sedangkan dua tahapan tersebut masih ada dalam ingatan masyarakat. Apakah ada alasan yang benar di mana agama dapat diganti dengan filsafat, selanjutnya dapat diganti dengan sains? ${ }^{13}$

Tahap berfikir rasional memang tidak bisa dilepaskan dengan sains dan modernisme, namun menyingkirkan agama adalah hal lain yang sulit dibuktikan A Periodisasi Sejarah Umat

dari kecemasan dunia yang takterpredeksi dan melepaskan dari cengkeraman dominasi kekuatankekuatan magis. ${ }^{14}$ Agama dapat saja menjadi mitos, namun tidak tertutup peluang untuk menjadi ilmu. Mitos sebagai sistem pengatahuan sudah ketinggalan zaman, meskipun masih ada orang yang hidup dalam dunia mitis. Pada era modern, bagi pemeluk agama tersedia peluang untuk menjadikan agama sebagai idiologi dan ilmu. ${ }^{15}$

Sesuai pengamatan Kuntowijoyo terhadap sejarah umat Islam Indonesia maka masyarakat telah melewati tiga periode, yang disebut sebagai periode mitos, periode idiologi dan periode ilmu. Periode mitos ditandai dengan cara berpikir pralogis (mistik) berbentuk magi. Periode mitos berlangsung sampai awal abad ke-20. Kemudian umat masuk periode idiologi yang ditandai dengan berdirinya Sarekat Islam (SI). Pada periode ini masyarakat sudah berpikir rasional tetapi masih non logis

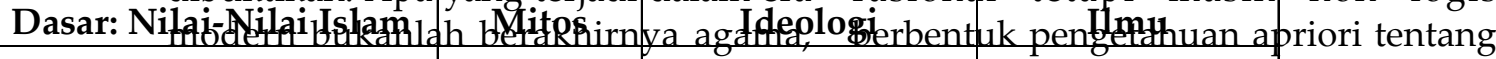

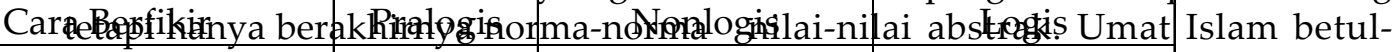
Bteratlikional yang dMgagitikan Alestgalk/ Apetaitidianggdxpomlatiti/berpikir logis pada rasionalitas yang dimanivestasikan dalam dimensi-dimensi kalkulabilitas dan kontrol sistematik atas semua aspek kehidupan manusia berdasarkan ketentuan-ketentuan dan ajaran-ajaran universal. Masyarakat modern terbebas periode ilmueyremisisitandai deidiologi Islam dengan keluarnya UU ormas pada tahun 1985. Dalam periode ilmu umat dalam kerangka pikir logis dicirikan dengan bentuk-bentuk berfikir obyektif, konkrit dan empiris. ${ }^{16}$

${ }^{15}$ Kuntowijoyo, Islam Sebagai Ilmu, h. 108

16 Ibid, h. 80-81 
Dengan tahapan-tahapan berfikir di atas, maka agama juga berevolusi sesuai dengan interpretasi pemeluknya. Agama tidak identik dengan dunia magi yang bakal ditinggalkan oleh umat modern. Tylor memberikan definisi minimalis terhadap agama yaitu kepercayaan pada wujud-wujud spiritual. Definisi tersebut walaupun minimalis, namun setidaknya akan memberikan suatu garis landasan bagi pendekatan interaksionis terhadap perjumpaan Tuhan-manusia yang didefinisikan secara budaya. ${ }^{17}$ Kuntowijoyo juga sepakat untuk melihat agama dalam relasi sosiologiskulturalnya, sehingga studinya lebih terfokus pada bagaimana ajaran agama itu diterapkan dan diamalkan oleh pemeluknya ketimbang bagaimana wujud (materi) doktrin-doktrin yang dimiliki oleh suatu agama.

Kuntowijoyo melihat bangunan agama dengan kacamata strukturalisme dengan iman sebagai kekuatan pembentuk dari bangunan agama tersebut (innate structuring capacity). Dari iman terbentuklah struktur dalam (deep structure) yang meliputi akidah (teologi), ibadah (kebaktian), akhlak, syari'ah, dan mu'amalah. Setelah struktur akan lahir struktur permukaan yang dapat diamati yaitu, keyakinan, shalat/puasa/ zakat/haji, moral/ etika, perilaku normatif, dan perilaku sehari-hari.

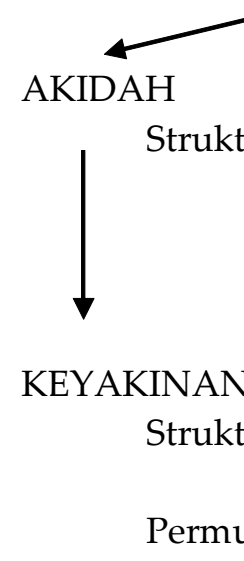

${ }^{17}$ Bryan S. Turner, Menggugat Sosiologi, h. 78 
Sebagai sebuah struktur ia juga memiliki ciri-ciri keseluruhan (wholeness) yaitu keterpaduan antar unsur dan tunduk kepada hukum yang mengatur keseluruhan, perubahan bentuk (transformation), yaitu kemampuan memperkaya diri dengan menambah bahan-bahan baru, dan mengatur diri sendiri (self-regulation). Bangunan agama sebagai sebuah struktur di atas dinamakan Kunto sebagai struktur transendental. Istilah transendental tersebut tidak dimaksudkan untuk menunjuk pada hal-hal yang metafisis dan spiritual tetapi bermakna melampaui, yaitu bagaimana agama bisa melampaui zamannya sehingga bisa mengalami transformasi. Kunto sangat tidak setuju dengan pemikiran yang menganggap agama sebagai abadi dan universal semata. $^{18}$

\section{Wahyu Sebagai Sumber Ilmu}

Bangunan ilmu-ilmu sosial modern menjadi titik pijak bagi Kunto untuk mengusulkan bangunan ilmu sosial baru. Ambisi Kunto adalah mengadakan revolusi sains sehingga yang diusulkannya mirip dengan kedudukan ilmu-ilmu sosial Marxis terhadap ilmuilmu sosial Barat yang dianggap kapitalis. Untuk itu Kunto melakukan kritik fundamental terhadap bangunan ilmu-ilmu sosial modern yang disebutnya sebagai ilmu sekuler dan menawarkan satu bangunan baru yang dinamakannya ilmu-ilmu integralistik. Meskipun demikian Kunto tidak ingin terjebak pada apologi sebagaimana yang sering terjadi pada ilmuan di lingkuangan religious studies yang berangkat dari wilayah normatif, maka secara tegas Kunto menyatakan bahwa,

Ilmu-ilmu sekuler tersebut adalah produk bersama seluruh manusia, sedangkan ilmu-ilmu integralistik (nantinya) adalah produk bersama seluruh manusia beriman. Karenanya, sekarang ini kami semua adalah produk, partisipan, dan konsumen ilmuilmu sekuler. Maka kami tidak akan gegabah memandang rendah dan menistakan ilmu-ilmu sekuler, tempat kami lahir. Sebaliknya, kami ingin menghormatinya dengan mengkritisi dan meneruskan perjalannya.

Fondasi ilmu-ilmu sekuler adalah filsafat rasionalisme abad modern yang bercorak antroposentris sebagai antitesa terhadap filsafat abad tengah yang bercorak teosentris. Dalam antroposentrisme, manusia menjadi pusat kebenaran, etika, kebijaksanaan, dan pengetahuan, sehingga terjadi diferensiasi (pemisahan) dengan wahyu Tuhan. Kebenaran ilmu tidak terletak di luarnya yaitu kitab suci, tetapi terletak dalam ilmu itu sendiri yaitu korespondensi (kecocokan ilmu dengan obyek) dan koherensi (keterpaduan) di dalam ilmu, antara bagian-bagian keilmuan dengan seluruh bangunan ilmu. Ilmu sekuler dengan demikian menganggap dirinya sebagai ilmu yang obyektif, value free, dan bebas dari kepentingan lainnya. Alur pertumbuhan ilmu sekuler adalah sebagai berikut:

Filsafat $\longrightarrow$ antroposentrisme $\longrightarrow$ diferensiasi $\longrightarrow$ ilmu sekuler

${ }^{18}$ Kuntowijoyo, Islam Sebagai Ilmu, h. 30 
Ilmu sekuler yang menjadi pilar utama peradaban modern ternyata tumbuh dari yang semula mengagungkan manusia menjadi penguasa atas manusia. Ilmu menggantikan kedudukan wahyu Tuhan sebagai petunjuk kehidupan, bahkan ilmu itu sendiri yang diramalkan akan menggantikan agama. Ambisi ilmu sekuler tersebut kenyataannya membawa malapetakan bagi manusia modern sehingga terjadi krisis nilai dan kehidupan yang hampa makna. Untuk itulah Kunto ingin mengakurkan kembali antara sains dan wahyu dengan istilah Ilmu integralistik, yaitu ilmu yang menyatukan (bukan sekedar menggabungkan) wahyu Tuhan dan temuan pikiran manusia, tidak akan mengucilkan Tuhan (sekulerisme) dan juga tidak mengucilkan manusia (other worldy asceticisme).

Ilmu-ilmu integralistik bercorak teoantroposentrisme yang menempatkan dua sumber pengetahuan, yaitu Tuhan yang berupa wahyu dan manusia yang berupa akal. Agama menyediakan tolok ukur kebenaran ilmu (benar, salah), bagaimana ilmu diproduksi (baik, buruk), dan tujuan-tujuan ilmu (manfaat, merugikan). Hak manusia adalah memikirkan dinamika internal ilmu sehingga menjadi ilmu yang obyektif. Meskipun ilmu integralistik lahir dari agama, namun menjadi gejala keilmuan yang obyektif yang dirasakan sebagai gejala keilmuan bukan norma oleh pemeluk agama lain, nonagama dan anti-agama. Alur ilmu-ilmu integralistik adalah sebagai berikut: ${ }^{19}$

\section{E. Arus Ulang Balik TeKs-Konteks}

Persoalan mendasar dalam ilmuilmu integralistik adalah bagaimana menjadikan agama yang bersumber pada wahyu sebagai sumber ilmu pengetahuan. Langkah pertama dalam menjawab masalah tersebut adalah dijadikan wahyu sebagai paradigma untuk perumusan teori. Paradigma yang dimaksud Kunto adalah sebagaimana dipahami Thomas Kuhn bahwa pada dasarnya realitas sosial itu dikonstruksi oleh mode of thought atau mode of inquiry tertentu yang pada gilirannya akan menghasilkan mode of knowing tertentu pula. Dengan pengertian tersebut paradigma al-Qur'an berarti suatu konstruksi pengetahuan yang memungkinkan umat Islam memahami realitas sebagaimana al-Qur'an memahaminya. Konstruksi pengetahuan tersebut akan menjadi dasar bagi umat untuk merumuskan desain besar mengenai sistem Islam termasuk sistem ilmu pengetahuannya. Dengan demikian paradigma al-Qur'an tidak hanya berhenti pada kerangka aksiologis tetapi juga dapat berfungsi memberi kerangka epistemologis. ${ }^{20}$

Paradigma al-Qur'an berarti mengubah cara pandang terhadap alQur'an yang selama ini dipegangi oleh umat sebagai kerangka rujukan normatif baik etika maupun hukum. Kuntowijoyo melihat bahwa selama ini ada dua cara pandang umat terhadap alQur'an sebagai kerangka rujukan.

1) dekodifikasi (penjabaran) yaitu menjaga nilai-nilai agama tetap sesuai aslinya dengan menjabarkan

\section{Agama $\longrightarrow$ teoantroposentrisme $\longrightarrow$ dediferensiasi $\longrightarrow$ ilmu integralistik}

${ }^{19}$ Kuntowijoyo, Islam Sebaga Ilmu, h. $51 \quad{ }^{20}$ Kuntowijoyo, Islam Sebagai Ilmu, h. 11-12 
al-Qur'an dan al-sunnah kedalam ilmu-ilmu agama. Cara pandang ini melahirkan gerakan dari teks ke teks, yaitu dari teks (al-Qur'an dan alsunnah) dijabarkan kedalam teks (tafsir, tasawuf, dan fiqh).

2) Islamisasi pengetahuan, yaitu usaha agar umat Islam tidak asal meniru metode-metode dari luar dengan mengembalikan pengetahuan pada pusatnya, yaitu tauhid. Dari tauhid diharapkan akan lahir tiga macam kesatuan, yaitu kesatuan pengetahuan, kesatuan kehidupan, dan kesatuan sejarah. Kesatuan pengetahuan berarti pengetahuan harus menuju kebenaran yang satu, kesatuan kehidupan berarti hapusnya perbedaan antara ilmu yang bebas nilai dan ilmu yang sarat nilai dan kesatuan sejarah berarti pengatahuan harus mengabdi kepada umat dan pada manusia. Islamisasi pengetahuan berarti mengembalikan pengetahuan pada tauhid, atau konteks kepada teks, supaya pengetahuan tidak lepas dari iman.

Dari kedua cara pandang terhadap teks al-Qur'an dan al-Sunnah tersebut di atas Kuntowijoyo merasa kurang mencukupi sehingga perlu diimbuhkan apa yang dinamakan demistifikasi. Kalau dekodifikasi teks dijabarkan kedalam teks dan islamisasi pengetahuan mengembalikan konteks ke teks, maka demistifikasi hendak menghubungkan teks dengan konteks. Selama ini harus diakui al-Qur'an kehilangan kontaknya dengan kenyataan, dengan realitas, dengan aktualitas, dan dengan kehidupan. Untuk itu gerakan yang diperlukan adalah demistifikasi atau dengan bahasa lain yang ditawarkan Kunto adalah pengilmuan Islam bukan
Islamisasi ilmu sehingga umat mengenal lingkungan dengan lebih baik, baik lingkungan fisik, sosial, simbolis, maupun lingkungan sejarah. ${ }^{21}$ Dalam kerangka demistifikasi atau pengilmuan Islam inilah proyek paradigma Islam sebenarnya berada. Memandang realitas dengan kacamata al-Qur'an berarti menghadapkan al-Qur'an dengan kenyataan dan kehidupan.

\section{F. Hermeneutika Wahyu}

Kunto ingin memulai dari al-Qur'an tetapi beliau tidak mau menghabiskan waktu dengan ribut soal tafsir al-Qur'an dengan menawarkan metodologi tafsir atau hermeneutika. Tujuan Kunto bukanlah bagaimana memahami teks, tetapi bagaimana menerapkan ajaranajaran sosial yang terkandung dalam teks lama pada konteks sosial masa kini tanpa mengubah strukturnya. ${ }^{22}$ Menurut Kunto pada dasarnya kandungan isi al-Qur'an terbagi menjadi dua bagian. Bagian pertama berisi konsep-konsep dan bagian kedua berisi kisah-kisah sejarah dan amstal. Pada bagian konsep-konsep terdapat konsep yang bersifat abstrak seperti konsep tentang Allah, malaikat, akhirat, ma'ruf, munkar dan lain sejenisnya dan juga terdapat konsep yang menunjuk kepada fenomena-fenomena konkret yang dapat diamati misalnya konsep tentang fuqara (orang-orang fakir), dhu'afa (golongan lemah), aghniya (golongan kaya), dan lainnya. Dengan konsep-konsep tersebut al-Qur'an bermaksud membentuk pemahaman yang komprehensif mengenai nilai-nilai ajaran Islam.

Pada bagian kedua yang berisi kisah-kisah historis dan amstal

\footnotetext{
${ }^{21}$ Kuntowijoyo, Islam Sebagai Ilmu, h. 6

${ }^{22}$ Ibid., h. 31
} 
(perumpamaan) al-Qur'an ingin mengajak dilakukaknnya perenungan untuk memperoleh wisdom (hikmah). Melalui kontemplasi terhadap kejadiankejadian atau peristiwa-peristiwa historis dan juga melalui metaformetafor yang berisi hikmah tersembunyi, manusia diajak merenungkan hakikat dan makna kehidupan.

Pendekatan sintetik berarti menarik pelajaran moral dari peristiwa-peristiwa empiris yang terjadi dalam sejarah. Dinamakan sintetik karena berusaha mensintesiskan penghayatan dan pengalaman subyektif dengan ajaranajaran normatif.. Peristiwa tersebut sebenarnya bersifat universal dan abadi, jadi yang dipentingkan dalam sejarah tersebut bukanlah data historisnya, bukan pula bukti obyektif empirisnya, tetapi ta'wil subyektif normatifnya. Kisah kesabaran Nabi Ayub misalnya menggambarkan tipe-tipe sempurna yang paling purba tentang betapa gigihnya kesabaran orang beriman menghadapi cobaan apapun. Kisah kezaliman Fir'aun menggambarkan arche-type mengenai kejahatan tiranik pada masa paling awal yang pernah dikenal oleh manusia.

Pendekatan sintetik saja tidak cukup karena hanya akan mengembangkan pespektif etik dan moral individu, padahal ajaran-ajaran Islam tidak berhenti pada transformasi individu tetapi juga pada level yang obyektif untuk transformasi kemasyarakatan. Sejarah telah membuktikan bahwa Islam merupakan suatu kekuatan perubahan sosial yang besar. Dengan demikian muncul satu pertanyaan bagaimana mewujudkan cita-cita profetik yaitu menciptakan masyarakat yang adil dan egaliter didasarkan pada iman. Menjawab pertanyaan inilah kunto menambahkan pendekatan sintetik dengan pendekatan kedua yaitu pendekatan analitik.

Pendekatan analitik memperlakukan al-Qur'an sebagai data, sebagai suatu dokumen mengenai pedoman kehidupan yang berasal dari Tuhan. Ayat-ayat al-Qur'an sesungguhnya merupakan pernyataan-pernyataan normatif yang harus dianalisis untuk diterjemahkan pada level yang obyektif. Itu berarti al-Qur'an harus dirumuskan dalam bentuk konstruk-konstruk teoritis. Sebagaimana kegiatan analisis data akan menghasilkan konstruk, maka demikian pula analisis terhadap pernyataan-pernyataan al-Qur'an akan menghasilkan konstruk-konstruk teoritis al-Qur'an. ${ }^{23}$

Dua pendekatan di atas tentu masih menyisakan banyak tugas karena alQur'an mungkin dari perspektif contentnya dapat dibagi kedalam dua bagian yaitu yang konseptual dan yang berupa kisah. Namun al-Qur'an merupakan kitab wahyu yang sakral meskipun juga memiliki ruang historisnya sendiri, dengan demikian bagaimanakah kemudian hubungan yang sakral dan tranhistoris dengan pengetahuan manusia yang historis. Menurut Kunto konstruk pengetahuan yang mengakui wahyu sebagai salah satu sumbernya berarti mengakui adanya struktur transendental sebagai referensi untuk menafsirkan realitas. Hal ini berarti tetap mengakui adanya ide yang yang murni yang sumbernya berada di luar manusia dan al-Qur'an tetap dipahami sebagai memiliki bangunan yang transendental

${ }^{23}$ Kuntowijoyo. Paradigma Islam: Interpretasi Untuk Aksi (Bandung: Mizan, 1998) h. 327 
atau sistem gagasan yang otonom dan sempurna.

Meskipun demikian untuk dapat diakui sebagai gagasan yang otonom dan sempurna, al-Qur'an memiliki kendala historis, untuk itu perlu dibebaskan dari konteks hostorisnya. Sebagaimana diketahui hampir setiap pernyataan al-Qur'an senantiasa mengacu kepada peristiwa-peristiwa aktual sesuai dengan konteks sejarahnya ketika ia diturunkan. Untuk itu menurut Kunto diperlukan metodologi penafsiran yang mampu mengangkat teks dari konteksnya, yaitu dengan mentransendensikan makna tekstual dari penafsiran kontekstual berikut biasbias historisnya. Dengan demikian makna teks yang transenden dan pesanpesan yang bersifat universal dapat dibebaskan dari bias historis akibat proses penurunannya yang seringkali merupakan respon terhadap realitas historis yang partikular.

Pada tahap makna universal itu nantinya diturunkan lagi dalam konstruk teori yang berlaku untuk membaca realitas kekinian juga tidak tertutup kemungkinan adanya bias subyektif. Namun menurut Kunto bias itu bersifat positif sepanjang pengaruh itu berasal dari kepentingan intelektual sang pemikir. Tidak ada masalah bagi Kunto kalau pengetahuan mengenai "grand design" wahyu dipengaruhi oleh pengetahuan tertentu, justru untuk memahami pesan-pesan al-Qur'an harus melibatkan semua warisan pengetahuan yang ada. Dulu cendekiawan muslim pernah meminjam "logika Yunani" untuk mengkonstruksikan filsafat Islam yang justru memacu perkembangan intelektual. Namun dalam hal pinjammeminjam pengetahuan lain perlu dipertahankan sikap kritis terhadap kerangka epistemik di balik pengetahuan tersebut. Dengan pengertian ini Kunto menolak eklektisisme yang menggabungkan pengetahuan tanpa seleksi. ${ }^{24}$

\section{G. Prinsip-Prinsip Dasar Ilmu Sosial Profetik}

Setelah cara pandang terhadap teks (al-Qur'an dan al-Sunnah) direkonstruksi sehingga teks bisa dihadapkan dengan realitas kehidupan empiris maka agenda berikutnya adalah bagaimana memahami realitas itu sendiri. Sebagaimana dinyatakan Kunto bahwa cita-citanya adalah untuk merumuskan ilmu-ilmu sosial profetik, bahkan ia pernah mengajukan proposal kepada Rektor UGM untuk pendirian Forum Studi Ilmu-Ilmu Profetik. Kunto meyakini bahwa ilmu-ilmu sosial sebagai muara dari pemikirannya mengingat suatu perspektif teoritis mengenai transformasi sosial Islam merupakan kebutuhan yang mendesak. Tanpa adanya teori-teori sosial Islam yang transformatif umat tidak akan dapat memahami kenyataan-kenyataan sosial dari pandangan Islam dan umat akan terombang-ambing dalam arus perubahan yang besar tanpa dapat melakukan upaya apapun untuk mengarahkannya.

Teks tidak hanya dijabarkan kedalam teks semata, namun teks harus mampu digunakan untuk membaca dan menjelaskan kenyataan-kenyataan obyektif dan empiris dalam masyarakat. Kenyataan-kenyataan obyektif dan empiris dalam masyarakat tersebut akan berbeda-beda pada tiap kelompok masyarakat di mana dan pada periode kapan ia tinggal. Untuk itu teori sosial Islam juga bukan sesuatu yang

\footnotetext{
${ }^{24}$ Kuntowijoyo. Paradigma Islam, h. 331-335
} 
permanen, ia dapat berubah-rubah sesuai dengan kondisi sosial masyarakat. Pada kondisi masyarakat industrial tentu dibutuhkan teori sosial yang berbeda dengan yang mungkin pernah dirumuskan pada masa lalu dalam asumsi-asumsi kitab figh yang berlatar belakang masyarakat agraris. Dengan demikian landasan normatif tetap permanen namun teori-teori sosial yang dibangun di atasnya tentu akan berubah-rubah sesuai perubahan sosial yang terjadi.

Kedudukan ilmu sosial 'barat' atau yang diistilahkan Kunto sebagai ilmu yang sekuler juga tidak sepenuhnya disingkirkan. Penyebutan sains barat sebagai sekuler tidaklah dimaksudkan sebagai dikotomisasi ilmu sehingga ilmu yang lahir dari agama menjadi eksklusif. Cita-cita untuk melahirkan revolusi sains dengan memasukkan wahyu sebagai salah satu sumber ilmu, juga tidak didasarkan pada sikap mental yang inferior dan ketakutan terhadap pengaruh dominasi sains barat. Sains yang lahir dari pemikir yang taat beragama harus bersifat terbuka terutama dalam berdialektika dengan semua bangunan ilmu pengetahuan, sehingga terjadinya peminjaman dan sintesis dengan ilmu barat tidaklah perlu dikhawatirkan. Ditegaskan oleh Kunto, bahwa pembangunan ilmu sosial profetik tidak mulai dari nol, dari sebuah vacuum. Semua peradaban dan semua agama mengalami proses meminjam dan memberi dalam interaksi mereka satu sama lain sepanjang sejarah. ${ }^{25}$

Sebagai rambu-rambu yang menjadi ukuran dasar dalam bangunan ilmu sosial profetik, Kunto menurunkannya dari surat Ali Imran ayat 110,

25 Kuntowijoyo, Islam Sebagai ilmu, h. 93-94
Kuntum khaira ummah ukhrijat linnasi ta'muruna bil ma'ruf wa tanhauna 'anil munkar watu'minuna billah. Ayat tersebut mengandung empat hal, yaitu 1) konsep tentang umat terbaik, 2) aktivisme sejarah, 3) pentingnya kesadaran, dan 4) etika profetik. Umat Islam tidak serta merta menjadi umat terbaik, namun harus memenuhi beberapa persyaratan, yaitu bekerja lebih keras dalam aktivisme sejarah yang bertumpu pada nilai-nilai Ilahiah. Kesadaran individu (superstrcture) tidaklah dibentuk oleh structure (basis sosial, kondisi material) dan juga bukan individu sendiri sebagaimana paham individualisme, eksistensialisme dan liberalisme, namun kesadaran dibentuk oleh Tuhan. Sebagai tujuan dan orientasi pengembangan ilmu harus diarahkan pada amar ma'ruf, nahi munkar dan tu'minuna billah. Amar ma'ruf berarti humanisasi dan emansipasi yaitu memanusiakan manusia, menghilangkan "kebendaan", ketergantungan, kekerasan dan kebencian dari manusia. Nahi munkar berarti liberasi yaitu melarang carok, memberantas judi, menghilangkan lintah darat, sampai membela nasib buruh dan mengusir penjajah. Sedangkan tu'minuna billah berarti transendensi, yaitu semua gerakan baik amar ma'ruf maupun nahi munkar harus memiliki rujukan ke atas yaitu kepada otoritas Tuhan. ${ }^{26}$

Sebagai contoh penurunan konsep normatif kedalam konstruk teoritis adalah pada sebuah hadits yang menyatakan, "kamu akan memperoleh kemenangan dan rezeki jika kamu mau berpihak kepada kaum yang lemah". Hadits ini menghantarkan pada perspektif teoritis mengenai paradigma

\footnotetext{
${ }^{26}$ Ibid, h. 96-97
} 
perubahan sosial. Konsep "kemenangan" dapat dirumuskan sebagai suatu gejala politik konsep "rezeki" sebagai gejala ekonomi. Dengan demikian perubahan politik dan ekonomi dapat terjadi jika ada advokasi dan pemihakan yang jelas kepada mereka yang lemah dan marginal karena merekalah sesungguhnya agen sejarah. ${ }^{27}$

Dengan demikian jelas bahwa teori sosial Islam sangat berorientasi kepada transformasi masyarakat sesuai dengan cita-cita sosial Islam. Meskipun demikian bahasa teori harus dibedakan dengan bahasa dakwah. Bahasa dakwah bersifat umum, sedangkan bahasa ilmu bersifat spesifik. Tugas ilmuan juga harus dibedakan dengan tugas pejabat, untuk itu tuduhan bahwa memikirkan ilmu akan sia-sia karena tidak segera dapat menjawab persoalan aktual tidak pada tempatnya. Menurut Kunto memang bukan tugas ilmu untuk menjawab persoalan praktis dan jangka pendek, itu adalah tugas pejabat. Urusan ilmu adalah perubahan dan transformasi sosial pragmatis jangka panjang. ${ }^{28}$

\section{H. Komentar dan KRITIK}

Dalam konstelasi sejarah pemikiran Islam Indonesia, Syafi'i Anwar memasukkan Kuntowijoyo kedalam gerbong bertipe transformatik. Di dalam gerbong itu dimasukkan Dawam Rahardjo, Adi Sasono, Kuntowijoyo dan Moeslim Abdurrahman. Ciri umum dari tipe pemikiran transformatik adalah bersifat praksis, dimana perhatian utamanya bukan pada aspek-aspek doktrinal dari teologi Islam tetapi pada masalah-masalah empiris dalam bidang

\footnotetext{
${ }^{27}$ Kuntowijoyo. Paradigma Islam, h. 345-346

${ }^{28}$ Ibid, h. 111
}

sosial-ekonomi, pengembangan masyarakat, penyadaran politik rakyat, orientasi keadilan sosial dan sebagainya. ${ }^{29}$ Namun Kunto memiliki kekhasan tidak hanya karena latar belakangnya sebagai aktivis Islam tetapi juga karirnya sebagai akademisi bahkan juga sebagai sastrawan. Arah pemikiran Kunto untuk mewujudkan Islam yang dapat menjadi kekuatan perubahan sangatlah jelas, namun berbeda dengan tokoh lain, Kunto mengemas pemikirannya dalam kerangka konseptual dan teoritik yang matang. Ia mengarahkan proyeknya untuk membangun ilmu sosial profetik sehingga mampu menjawab berbagai hal yaitu bagaimana Islam dapat menjadi kekekuatan paradigmatik sehingga umat dapat memasuki masa industrialisasi tetapi sekaligus menjadi kekuatan kritik bagi umat sehingga tidak terbelunggu dalam sistem kapitalisme.

Dalam konteks bangunan pemikirannya mengenai paradigma Islam, Kunto dapat disejajarkan dengan intelektual muslim kelas dunia kontemporer seperti al-Jabiri, Syahrur, atau Nashr Hamid Abu Zayd. Kegelisahan Kunto mengenai lemahnya Islam dalam bangunan keilmuan yang konstruktif dan transformative merupakan kegelisahan yang juga dirasakan oleh Syahrur, seorang Insinyur asal Damaskus yang menekuni pemikiran Islam. Sebagaimana dalam karya utama Syahrur al-Kitab wa alQur'an, Qira'ah Mu'ashirah ia menyebutkan beberapa masalah umat Islam di antarnya:

29 M. Syafi'i Anwar, Pemikiran dan Aksi Islam Indonesia, Sebuah Kajian Politik Tentang Cendekiawan Muslim Orde Baru (Jakarta: Paramadina, 1995) h. 162 
1. Pemikiran Islam belum memanfaatkan konsep-konsep dalam filsafat humaniora dan tidak berinteraksi dengan dasar-dasar teorinya. Tidak mungkin seluruh hasil pemikiran manusia sejak zaman Yunani hingga saat ini adalah salah semua. Pasti di antaranya ada yang sempit ada dan ada yang luas, ada yang relevan dan ada yang tidak relevan. Meskipun demikian sebelum berinteraksi dengan hasil pemikiran tersebut, setiap muslim harus memiliki standar fleksibel yang memungkinkan kita berinteraksi dengan orang lain tanpa ada rasa takut.

2. Tidak adanya teori Islam kontemporer dalam ilmu humaniora yang disimpulkan secara langsung dari al-Qur'an. Sebuah teori yang memberi metode tentang cara berpikir ilmiah pada diri setiap muslim, memberikan rasa percaya diri, dan berani berinteraksi dengan nilai apapun yang dihasilkan manusia tanpa melihat aqidahnya. ${ }^{30}$ Dengan paradigma Islam dan ilmuilmu sosial profetik Kunto telah menjawab kegelisahan umat Islam sebagaimana dinyatakan Syahrur. Dengan latar belakang ilmunya dalam bidang sejarah sosial justru memudahkan kajian Kunto untuk mengembalikan misi utama al-Qur'an sebagai petunjuk bagi manusia (huda li al-nas). Penguasaan Kunto dalam ilmuilmu sosial memudahkan ia untuk membaca masalah-masalah empiris yang melanda umat dan mendialogkannya dengan teks, sehingga hubungan teks

30 Muhammad Syahrur, al-Kitab wa al-Qur'an, Qira'ah Mu'ashirah (Damaskus: al-Ahali, 1990) h. 29-32 dengan konteks menjadi hidup dan dinamis.

Kelemahan Kunto di antaranya pada idenya mengenai paradigma al-Qur'an dan pendekatannya dalam memahami al-Qur'an. Kunto memang tidak ingin bertele-tele dalam kajian tafsir atau hermeneutik, namun harapannya untuk menerapkan misi sosial Islam akan kandas bila tidak didukung dengan kerangka metodologi dalam memahami ayat-ayat al-Qur'an. Kunto mungkin dengan mudah menghubungkan satu ayat al-Qur'an dengan teoriteori sosial tertentu dan mengungkapkannya dengan perspektif dan bahasa keilmuan, namun bila hal itu tidak dibangun dengan argumentasi metode tafsir atau hermeneutik, Kunto akan dengan mudah dituduh subyektif.

Sebagai contoh subyektifitas Kunto dalam menafsirkan ayat adalah kajiannya terhadap Surat al-Nisa' ayat 75 ,

Mengapa kamu tidak mau berperang di jalan Allah dan (membela) orang-orang yang lemah baik laki-laki, wanitawanita maupun anak-anak yang semuanya berdoa: "Ya Tuhan kami, keluarkanlah kami dari negeri Ini (Mekah) yang zalim penduduknya dan berilah kami pelindung dari sisi Engkau, dan berilah kami penolong dari sisi Engkau!"

Sebagaimana dipaparkan di atas, Kunto menyandarkan bukan meng'atafkan kata wa al-mustad'afin dengan fi sabilillah, sehingga bagian ayat tersebut dimaknai jalan kaum teraniaya yang dikemudian diturunkan Kunto dalam koteks misi perjuangan politik umat Islam sebagai perubahan 
struktural. Memang pendapat Kunto tersebut tidak sepenuhnya menjauh dari tradisi penafsiran al-Qur'an. Sebagaimana pendapat Quraish Shihab, al-mustad'afin secara harfiah berarti orang-orang yang diperlemah. Dari segi redaksi, ia mencakup segala macam manusia yang tidak diberdayakan oleh suatu sistem. ${ }^{31}$ Jadi sasarannya adalah kebobrokan struktural, namun konteks ayat di atas adalah seruan kepada umat Islam agar bertekad membebaskan keluarga dan saudara-saudara mereka yang masih ada di Makkah yang dianiaya dan ditindas oleh penguasa di Makkah. Sehingga sesuai konteks ayat, gerakan yang diperlukan tidak hanya mencakup perubahan struktural, tetapi juga perlawanan untuk pembebasan saudara-saudara sebangsa setanah air dan seiman dari penindasan lawan yang yang dzalim.

Kelemahan lain adalah soal konsep paradigma al-Qur‘an. Sebagaimana disadari oleh Kunto, cara berfikir seseorang tidak sama dengan anjing melihat tulang, manusia berfikir melalui kategori-kategori yang dinamakan paradigma, sehingga diimpikan oleh Kunto agar umat Islam melihat realitas sebagaimana al-Qur'an melihatnya. Namun perlu diperhatikan bahwa cara pandang manusia atau umat Islam terhadap al-Qur'an juga tidaklah tunggal, cara pandang itu juga dibentuk oleh realitas sosial-budaya dimana dan kapan umat itu bermasyarakat. Sebagaimana kritik Syahrur bahwa tidak adanya metode ilmiah yang rigerous terhadap teks al-Qur'an akan berimbas pada subyektivitas. Hal itu dicontohkan

31 M. Quraish Shihab, Tafsir al-Misbah, Pesan, Kesan dan Keserasian al-Qur'an (Jakarta: Lentera Hati, 2005) v.2, h. 508-509 dengan adanya prakonsepsi terhadap semua masalah sebelum kajian dilakukan. Contohnya penelitian mengenai "Posisi Perempuan dalam Islam". Para peneliti muslim berkesimpulan terlebih dahulu sebelum mengadakan penelitian. Mereka berasumsi bahwa posisi perempuan dalam Islam sudah proporsional dan Islam adalah agama yang bersikap paling adil terhadap perempuan. Kemudian peneliti tersebut mengarang buku mengenai perempuan. ${ }^{32}$

Sebagai contoh cara pandang Kunto terhadap al-Qur'an yang diwarnai oleh pandangan hidupnya sebagai aktivis salah satu gerakan Islam di Indoneisa adalah motivasinya untuk mengeluarkan jurus obyektivikasi nilainilai al-Qur'an karena umat Islam wajib menerapkan hukum Allah sesuai pemahaman terhadap surat al-Maidah ayat 44-46. Menurut Quraish Shihab dengan menyandarkan kepada pendapat mayoritas ulama, ayat tersebut ditujukan bagi yang melecehkan hukum Allah dan yang mengingkarinya. Kekufuran, kefasikan dan kezaliman bagi orang-orang Islam tidak sama dengan kekufuran bagi orang-orang non Islam. Kekufuran muslim adalah pengingkaran nikmat. ${ }^{33}$ Dengan demikian masalahnya adalah bukan pada kewajiban atau pengingkaran terhadap keberadaan al-Qur'an, tetapi bagaimana memaknai hukum-hukum Allah (syariat) dalam konteks kekinian.

Sekali-lagi kelemahan-kelemahan di atas tidak ingin menghakimi pikiran Kunto, karena meskipun Kunto menempuh jalan pintas tetapi ia mampu mencapai kesimpulan yang dapat

${ }^{32}$ Muhammad Syahrur, al-Kitab, h. 32

33 M.Quraish Shihab, Tafsir al-Misbah, v. 3, h. 105-105 
dipertanggungjawabkan. Masalahnya adalah bagaimana kerangka konseptual yang ditawarkan Kunto bisa digunakan oleh umat Islam dan khususnya kalangan akademik muslim untuk mengkaji al-Qur'an. Di sinilah pertanggungjawaban metodologi tafsir yang lebih memadai sangat diperlukan. Namun cita-cita tersebut mungkin merupakan agenda bagi generasi setelah pak Kunto, karena terlepas dari semua kekurangan tersebut Kuntowijoyo adalah pahlawan yang menghantarkan umat Islam untuk mulai kembali berfikir tentang bangunan keilmuan. Sebagaimana dinyatakan oleh Syafi'i Anwar dalam kata pengantarnya pada bukunya Identitas Politik Umat Islam, Kunto merupakan sosok Intelektual yang berani dalam pengertian berani hidup sederhana tanpa harta, pangkat dan kekuasaan sehingga memungkinkan untuk membuat karya yang komprehensip. Banyak impian beliau yang belum terwujud, sebagaimana ia ceritakan kepada beberapa editor bukunya bahwa ia ingin menulis mengenai "Seri Islam dan Industrialisasi", dan beberapa buku mengenai kerangka filosofis dan metodologis dalam sebuah proyek besar yang disebutnya pengilmuan Islam.

\section{Kesimpulan}

Dari pemaparan di atas rancang bangun ilmu sosial profetik yang diusulkan Kuntowijoyo dapat disimpulkan dengan bagan sebagai berikut:

\begin{tabular}{|c|c|c|}
\hline 1. & Origin (Sumber) & $\begin{array}{l}\text { Nash/teks/wahyu } \\
\text { Rasio } \\
\text { Empiri }\end{array}$ \\
\hline 2. & $\begin{array}{l}\text { Metode (Proses } \\
\text { dan Prosedur) }\end{array}$ & $\begin{array}{l}\text { Sintetik } \\
\text { Analitik }\end{array}$ \\
\hline 3. & $\begin{array}{l}\text { Approach } \\
\text { (Epistemologi) }\end{array}$ & $\begin{array}{l}\text { Sosiologi Agama } \\
\text { Humaniora } \\
\text { Humanisme Teosentris } \\
\text { Historis }\end{array}$ \\
\hline 4. & $\begin{array}{l}\text { Theortytical } \\
\text { Framework } \\
\text { (kerangka Teori) }\end{array}$ & $\begin{array}{l}\text { - Revolusi Sains. (Ilmu Sosial Profetik VS Ilmu Sosial } \\
\text { Sekuler, Integralisme VS Diferensiasi, Masjid VS } \\
\text { Pasar) } \\
\text { - Strukturalisme Transendental (Tuhan (Iman) } \\
\text { membentuk kesadaran individu dan membangun } \\
\text { struktur keagamaan }\end{array}$ \\
\hline 5. & $\begin{array}{ll}\text { Fungsi dan } & \text { dan akal } \\
\text { peran }\end{array}$ & Salah satu sumber pengetahuan \\
\hline 6. & $\begin{array}{l}\text { Types of } \\
\text { Argumen }\end{array}$ & Dialektika histories \\
\hline
\end{tabular}

94 Dialog No. 68, Tahun XXXII, Nopember 2009 
Dengan bagan di atas setidaknya Qur'an sebagai sumber ilmu adalah telah terbuka lembaran baru hubungan merumuskan nilai-nilai subyektif agama dan sains yang konstruktif. normatife al-Qur'an untuk kemudian Setidaknya melalui tulisan-tulisannya, dengan pendekatan analitik diturunkan

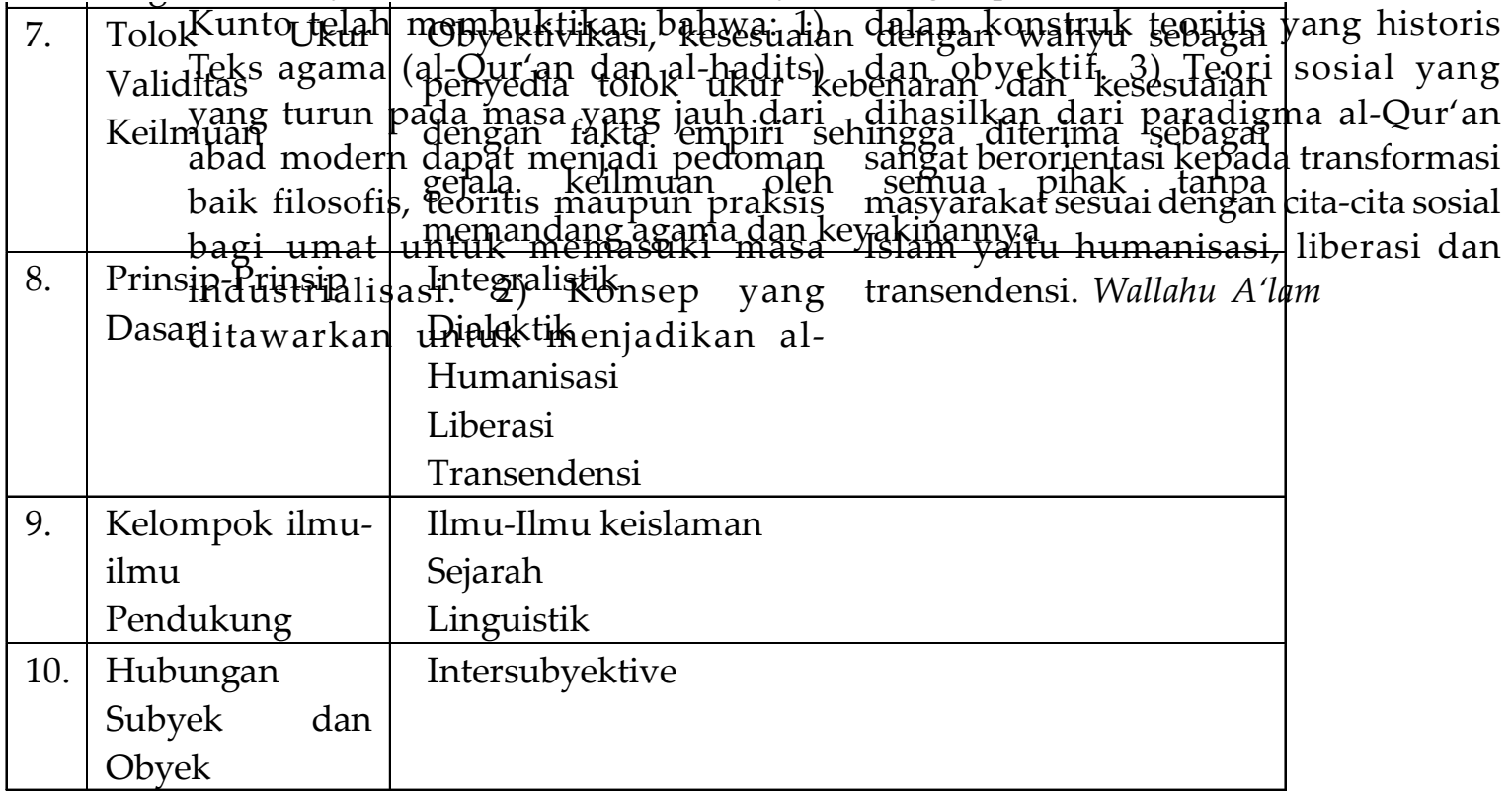


Abdurrahman, Moeslim, Islam Transformatif, Jakarta: Pustaka Firdaus, 1997

Anwar, M. Syafi'i, Pemikiran dan Aksi Islam Indonesia, Sebuah Kajian Politik Tentang Cendekiawan Muslim Orde Baru, Jakarta: Paramadina, 1995

al-Jabiri, Muhammad Abid, Post Tradisionalisme Islam, Penerjemah: Ahmad Baso, Yogyakarta: LKiS, 2000

Kuntowijoyo. Paradigma Islam: Interpretasi Untuk Aksi, Bandung: Mizan, 1998 Identitas Politik Umat Islam, Bandung: Mizan, 1997 , Islam Sebagai ilmu,
Epistemologi, Metodologi, dan Etika, Bandung: Teraju Mizan, 2004

Rahardjo, M. Dawan, Intelektual Intelegensi dan Perilaku Politik Bangsa, Bandung: Mizan, 1999

Rolston, Holmes, Science and Religion a Critical Survey, New York: Random House, 1987

Shihab, M. Quraish, Tafsir al-Misbah, Pesan, Kesan dan Keserasian alQur'an, Jakarta: Lentera Hati, 2005

Syahrur, Muhammad, al-Kitab wa alQur'an, Qira'ah Mu'ashirah, Damaskus: al-Ahali, 1990

Zaid, Nashr Hamid Abu, Mafhum alNash, Dirasah fi 'Ulum al-Qur'an, Kairo: al-Hay'ah al-Mishriyah alAmmah li al-Kitab 